Herz 2020 • 45:632-636

https://doi.org/10.1007/s00059-020-04953-9

Published online: 15 June 2020

(c) The Author(s) 2020

\section{Background}

Cardiovascular diseases and cancer represent the most frequent causes for mortality and morbidity in industrialized countries [1]. Both diseases share common risk factors such as lifestyle and age and many patients are affected by both disease types. Nevertheless, for decades, in clinical routine cardiovascular diseases and cancer have been viewed separately and interdisciplinary treatment concepts were rarely considered. Likewise, intensive basic and clinical research has been performed in both fields and, although cancer and cardiovascular pathologies share many pathways, interdisciplinary cross-talk between researchers in the cancer and cardiovascular field was scarce. However, with the development of highly effective antitumor therapies, the prognosis and long-term survival of cancer patients improved, leading to an increased incidence of cardiovascular problems in these patients [2]. Furthermore, the cardiotoxic side effects of anticancer treatments such as irradiation and anticancer drugs, alone or in combination, became evident and have increasingly moved into the focus of the cardiovascular discipline [3]. Moreover, recent studies discovered interesting genetic interactions between the two disease entities, for example, heart failure was shown to promote transition of pretumor stages and tumor growth [4]. In addition, cancer predisposition syndrome mutations (CPS) are more frequent in patients with peripartum cardiomyopathy (PPCM) compared

The authors T.J. Pfeffer and S. Pietzsch contributed equally to the manuscript.

Tobias J. Pfeffer · Stefan Pietzsch • Denise Hilfiker-Kleiner

Department of Cardiology and Angiology, Hannover Medical School, Hannover, Germany

\title{
Common genetic predisposition for heart failure and cancer
}

with age-matched women in the normal population [5].

Based on these connections between cancer and heart failure, interdisciplinary teams with specialized oncocardiology services emerged and oncocardiology became a new clinical and research field [6]. In the present review, we summarize current knowledge on the pathomechanistic connections between cancer and cardiovascular diseases with a specific focus on the role of genetics and the multihit hypothesis connecting both disease types.

\section{Common risk factors}

Cancer and cardiovascular diseases display a multifactorial pathogenesis and many aspects of their pathogenesis are shared among the two entities. While some risk factors seem to be cancer specific, i.e., cancer-causing viral infections [7] or specific for cardiomyopathies (high blood pressure, cardiomyopathy-causing gene variants), many other risk factors are common for both disease types (e.g., smoking, metabolic syndrome, irradiation, age, air pollution, and environmental toxins).

However, besides the long list of well-described common risk factors, recent studies showed that cardiovascular diseases and cancer also directly influence each other. In this regard, it is a well-known fact that many anticancer drugs, e.g., anthracyclines (such as epirubicin [8], daunorubicin [9], doxorubicin [10], or idarubicin [11]), antibodies (trastuzumab [12], bevacizumab [13]), or small molecules (such as dasatinib, sunitinib [14], sorafenib [15]) have cardiotoxic side effects and can cause cardiovascular diseases such as heart failure, arrhythmias, atherosclerosis, and thrombosis. These cardiovascular diseases can occur acutely during anticancer treatment or even years after the initial anticancer treatment. Far more than half of all childhood cancer survivors develop treatment-related chronic health issues later in life, of which cardiovascular complications make up a substantial fraction [16].

Another aspect in this context is the potential effect of immunosenescence, a term describing the gradual deterioration of the immune system during aging. Increased levels of inflammatory cytokines, released by senescent cells in the bone marrow niche, contribute to hematopoietic stem cell aging, which can cause an increased susceptibility to infections, cancer, and cardiovascular diseases [17]. A high incidence of age-related clonal hematopoiesis of indeterminate potential (CHIP) mutations might be a result of a senescent hematopoietic system, favoring, e.g., ten-eleven translocation 2 (TET2; [17]). Furthermore, experimental studies revealed that tumors can directly impact on the heart, e.g., by modifying cardiac metabolism resulting in impairment of cardiac function. Reduction of systemic insulin levels in melanoma tumor-bearing mice due to consumption of large amounts of glucose by the tumor tissue interfered with cardiac glucose uptake and was associated with cardiac atrophy and dysfunction [18]. Another study proposed that oncometabolite d-2-hydroxyglutarate, released by leukemic cells, induced contractile dysfunction and histone modifications [19].

Conversely, experimental data indicate that cardiovascular diseases can also promote the development of cancer dis- 


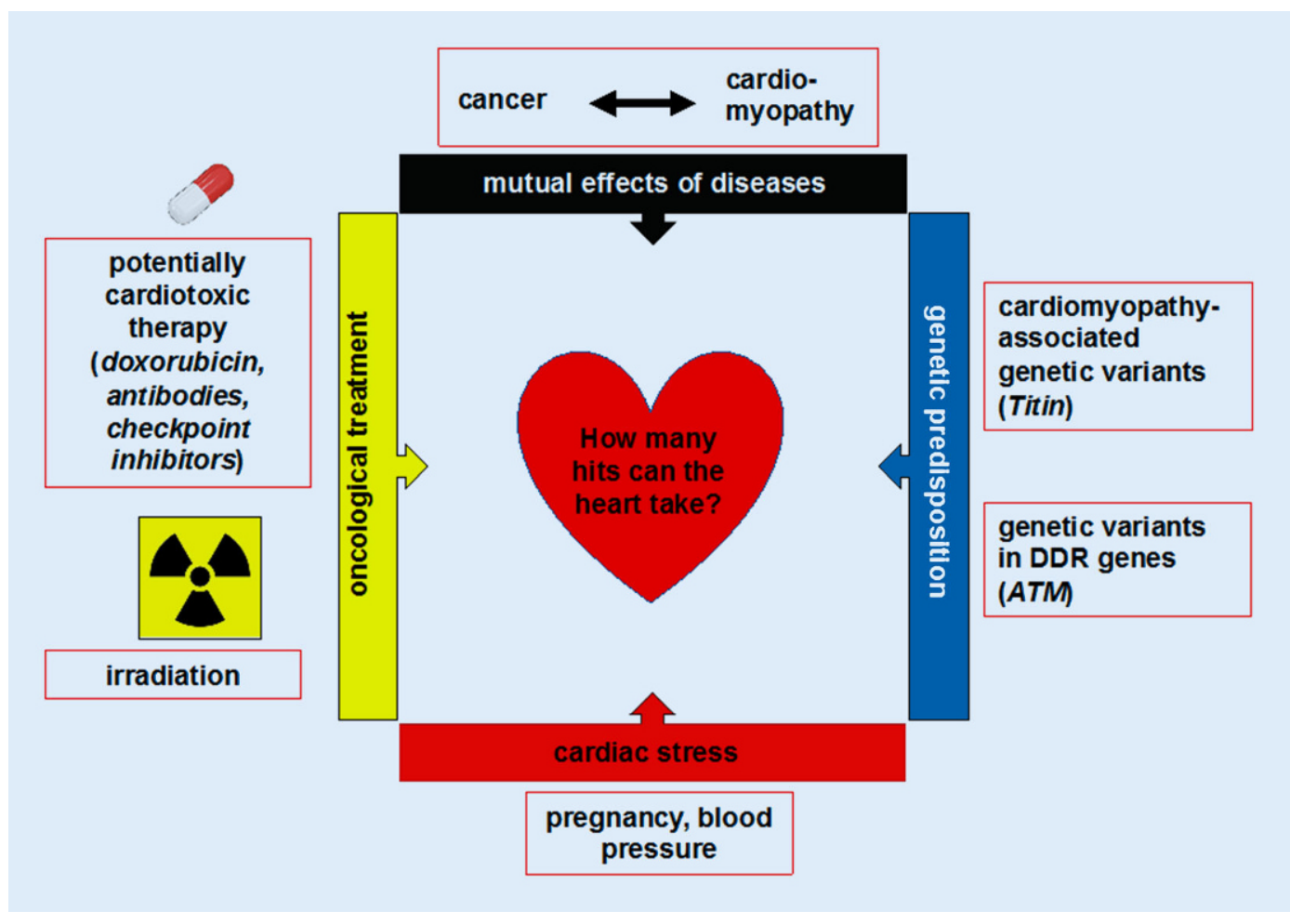

Fig. $1 \varangle$ Multi-hithypothesis in oncocardiology. Combination of multiple "hits" from oncological treatment, genetic predisposition, cardiac stress events, or mutual predisposing effects of disease entities might trigger late-onset cardiotoxicity

eases, as shown by Meijers et al. that heart failure stimulates the transition of pre-tumor stages and tumor growth in a mouse model, which is caused by cardiac excreted factors [4]. Epidemiological studies further show that prevalent heart failure increases the risk of developing cancer [20-23].

\section{Genetic background}

Besides these well-described risk factors, genetic background plays an important role in the pathogenesis of both entities. Several studies demonstrated that genetics might not only contribute to the pathogenesis of each disease type, but also connect cardiovascular diseases and cancer.

\section{Somatic mutations}

Somatic mutations such as the aforementioned CHIP mutations, which physiologically accumulate during the aging process and are known to increase the risk of hematological neoplasia, became the focus of several working groups in the field of oncocardiology. Besides the well-described effects on the risk of hematological neoplasia, recent studies showed that CHIP mutations also accelerate the development of cardiovascular diseases such as atherosclerosis, coronary heart disease, and ischemic stroke, and worsened the outcome of heart failure patients [24]. Data from experimental studies show that mice with TET2deficient hematopoietic cells-the first gene reported to exhibit somatic mutations in blood cells in individuals with clonal hematopoiesis without hematological malignancies [25]-display an increase in atherosclerotic plaque size [26]. These data are further supported by recent whole-exome-sequencing studies, showing that CHIP mutations are associated with an increased risk of coronary heart disease and ischemic stroke [27].

\section{Systemic mutations}

There is evidence that patients with mutations associated with cardiomyopathies have more sensitive responses to the cardiotoxic side effects of anticancer treatments. Genome-wide association studies (GWAS) identified variants in genes, belonging to the cardiac remodeling pathway, which influence left ventricular functional changes after anthracycline exposure [28]. Most promi- nent are genetic variants associated with dilated cardiomyopathy, especially Titin truncating variants that increase the risk of cancer therapy-induced cardiomyopathies [29]. Therefore, genetic testing to assess the individual risk of chemotherapy cytotoxicity has been suggested [30]. Along this line, pathogenic Titin variants are frequent in patients with peripartum cardiomyopathy (PPCM; [31]) who also have a 16-fold higher risk of cancer compared with age-matched healthy women in the normal (German) population [5]. The fact that cancer occurred before as well as after the onset of PPCM underlines the complex connection between these two disease entities. Whole-exome sequencing revealed a high incidence of mutations in genes associated with either cardiomyopathies, including Titin variants, and/or the DNA damage response/ repair system (DDR) in PPCM patients with a history of cancer. The prevalence of cardiomyopathy-associated gene variants was similar in PPCM patients with and without cancer but, as mentioned earlier, it may have increased the risk for subclinical cardiac damage after antitumor treatments and as a consequence the risk of developing PPCM later in life [29]. 
Mutations in DDR genes resulting in loss of function, downregulation, or even upregulation of the respective protein can predispose individuals to the development of cancer and other diseases [32]. The observation that DDR mutations appeared almost exclusively in PPCM patients with a history of cancer may, on one hand, explain that both disease entities emerged in these patients and, on the other hand, may point to a potential role of DDR genes in the protection of the maternal heart from pregnancy-induced stress. Furthermore, DDR mutations may also increase the risk of cardiotoxicity from antitumor therapies, as seen, e.g., in breast cancer patients with BRCA1 and BRCA2 mutations who have a higher risk of cardiac toxicity following anthracycline-based chemotherapy [33]. In addition, the relevance of DDR targets, e.g., DNA damage-inducible transcript 4 (Ddit4), for pathogenic alterations in pregnancy, for instance, of preeclampsia, a pregnancyspecific hypertensive disorder, has also been described [34]. Thus, mutations in DDR genes, which predispose to cancer, might also become relevant in the heart during phases of increased cardiac stress such as pregnancy or delivery and may thereby contribute to the development of preeclampsia and PPCM. Based on the potential influence of gene variants associated with cardiomyopathies and/or CPS, patient derived iPSC models [39] should be further explored for pretherapeutic pharmacogenetic testing [40] and personalized treatment concepts, to enhance efficacy of anti-tumor treatment and minimize adverse side effects on the cardiovascular system.

\section{Multi-hit hypothesis}

Hence, an important aspect in the pathogenesis of cancer and cardiovascular diseases is the multi-hit hypothesis, which states that the risk of cancer and/or cardiovascular diseases increases the more of the aforementioned factors are combined in a patient. The multi-hit hypothesis is originally a well-established model for the development of cancer, proposed by Alfred Knudson [35]. In an observational study of 48 cases of retinoblas-

Herz 2020 - 45:632-636 https://doi.org/10.1007/s00059-020-04953-9

(c) The Author(s) 2020

\section{T. J. Pfeffer · S. Pietzsch · D. Hilfiker-Kleiner}

\section{Common genetic predisposition for heart failure and cancer}

\section{Abstract}

Cardiovascular diseases and cancer are major causes of mortality in industrialized societies. They share common risk factors (e.g., genetics, lifestyle, age, infection, toxins, and pollution) and might also mutually promote the onset of the respective other disease. Cancer can affect cardiac function directly while antitumor therapies may have acute- and/or late-onset cardiotoxic effects. Recent studies suggest that heart failure might promote tumorigenesis and tumor progression. In both cancer and cardiovascular diseases, genetic predisposition is implicated in the disease onset and development. In this regard, genetic variants classically associated with cardiomyopathies increase the risk for toxic side effects on the cardiovascular system. Genetic variants associated with increased cancer risk are frequent in patients with peripartum cardiomyopathy complicated by cancer, pointing to a common genetic predisposition for both diseases. Common risk factors, cardiotoxic antitumor treatment, genetic variants (associated with cardiomyopathies and/or cancer), and increased cardiac stress lead us to propose the "multi-hit hypothesis" linking cancer and cardiovascular diseases. In the present review, we summarize the current knowledge on potential connecting factors between cancer and cardiovascular diseases with a major focus on the role of genetic predisposition and its implication for individual therapeutic strategies and risk assessment in the novel field of oncocardiology.

\section{Keywords}

Oncocardiology - Cardiovascular disease . Cancer therapy · Genetic susceptibility · Risk factors

\section{Gemeinsame genetische Prädisposition für Herzinsuffizienz und Krebs}

\section{Zusammenfassung}

Kardiovaskuläre Erkrankungen und Krebserkrankungen gehören zu den häufigsten Todesursachen in der industrialisierten Welt. Beide Krankheitstypen weisen gemeinsame Risikofaktoren (z. B. genetische Prädisposition, Lebensstil, Alter, Infektionen, Toxine und Umweltverschmutzung) auf und können sich gegenseitig begünstigen. Krebserkrankungen beeinträchtigen die Herzfunktion einerseits direkt, und andererseits sind viele onkologische Therapiemethoden mit einem erhöhten Risiko für akute und später auftretende kardiotoxische Nebenwirkungen assoziiert. Umgekehrt gibt es Evidenzen, dass ein geschädigtes Herz die Entstehung und Progression von Tumoren begünstigt. Sowohl für Herz- als auch Krebserkrankungen ist bekannt, dass genetische Prädispositionen die Entstehung und den Krankheitsverlauf beeinflussen. Genetische Varianten in klassischerweise kardiomyopathieassoziierten Genen können zudem die Sensitivität gegenüber kardiotoxischen Chemotherapeutika erhöhen. Patientinnen mit peripartaler Kardiomyopathie haben beispielsweise ein erhöhtes Krebsrisiko, was mit einer gehäuften
Prävalenz für krebsprädisponierende Mutationen einhergeht und damit eine gemeinsame genetische Prädisposition für beide Erkrankungen nahelegt. Die gemeinsamen Risikofaktoren, die gegenseitige Beeinflussung durch den genetischen Hintergrund und kardiotoxische Antitumortherapien und erhöhter kardialer Stress sind vermutlich zumindest teilweise für die Koinzidenz von Krebserkrankungen und kardiovaskulären Erkrankungen verantwortlich und führen zur "Multi-Hit-Hypothese“. In diesem Review werden potenzielle Gemeinsamkeiten und Interaktionen zwischen Krebserkrankungen und kardiovaskulären Erkrankungen, mit Fokussierung auf gemeinsame genetische Prädispositionen und die Multi-Hit-Hypothese, zusammengefasst und im Hinblick auf ihre Bedeutung für personalisierte Therapien und Risikobeurteilung diskutiert.

\section{Schlüsselwörter}

Onkokardiologie · Herz-Kreislauf-Erkrankungen · Krebstherapie · Genetische Prädisposition · Risikofaktoren 
toma, he concluded that the development of retinoblastoma is caused by two mutational events [35]. Today this hypothesis is broadly accepted, elucidating the development of many forms of cancer [36, 37]. Besides explaining the pathogenesis of cancer, this hypothesis was also transferred to the field of oncocardiology (- Fig. 1). The hypothesis supports the observation that cancer patients often do not show any acute cardiovascular effects, but years later cardiovascular pathologies emerge that are likely to be late effects of antitumor therapies. For example, hematologic cancer and corresponding anticancer treatment in children and adolescents has a good survival rate and persisting heart failure is not frequent. However, if a second stressor-i.e., pregnancy, diabetes, or high blood pressure-appears later in life, it may trigger late-onset cardiomyopathy in these patients [38].

\section{Conclusion}

Genetic background plays an important role in disease predisposition for cancer and heart failure as well as for (cardio)-toxic response to antitumor therapy. In this regard, somatic (clonal hematopoiesis of indeterminate potential [CHIP]) and germline mutations (DNA damage response/repair [DDR]) associated with a higher cancer risk may also promote cardiovascular disease, on the one hand, and increase the risk for cardiotoxic effects of antitumor treatments, on the other hand. Conversely, pathophysiological alterations during genetic cardiomyopathies, i.e., metabolic impairment and altered circulation factors, may promote the development and progression of cancer and may increase the toxic effect of antitumor therapies on the heart. Therefore, genetic analyses and pretherapeutic pharmacogenetic testing, may provide important information for optimal anti-tumor therapy with minimal (cardiovascular) side effects to ensure best possible outcome for tumor patients.

\section{Corresponding address}

Denise Hilfiker-Kleiner, PhD

Department of Cardiology and Angiology,

Hannover Medical School

Carl-Neuberg Str. 1, 30625 Hannover, Germany

hilfiker.denise@mh-hannover.de

Acknowledgment. This work was supported by the Fondation Leducq.

\section{Compliance with ethical guidelines}

Conflict of interest. T.J. Pfeffer, S. Pietzsch and D. Hilfiker-Kleiner declare that they have no competing interests.

For this article no studies with human participants or animals were performed by any of the authors. All cited studies in which authors of this manuscript were involved were in accordance with the ethical standards indicated in each case.

Open Access. This article is licensed under a Creative Commons Attribution 4.0 International License, which permits use, sharing, adaptation, distribution and reproduction in any medium or format, as long as you give appropriate credit to the original author(s) and the source, provide a link to the Creative Commons licence, and indicate if changes were made. The images or other third party material in this article are included in the article's Creative Commons licence, unless indicated otherwise in a credit line to the material. If material is not included in the article's Creative Commons licence and your intended use is not permitted by statutory regulation or exceeds the permitted use, you will need to obtain permission directly from the copyright holder. To view a copy of this licence, visit http://creativecommons.org/licenses/by/4.0/.

\section{References}

1. World Health Organisation (2016) Global health estimates 2015: deaths by cause, age, sex, by country and by region, 2000-2015

2. Petek BJ, Greenman C, Herrmann J, Ewer MS, Jones RL (2015) Cardio-oncology: an ongoing evolution. Future Oncol 11(14):2059-2066

3. Habibian M, Lyon AR (2019) Monitoring the heart during cancer therapy. Eur Heart J Suppl 21(Supp M):M44-M49

4. Meijers WC, Maglione M, Bakker SJL et al (2018) Heart failure stimulates tumor growth by circulating factors. Circulation 138(7):678-691

5. Pfeffer TJ, Schlothauer S, Pietzsch S et al (2019) Increased cancer prevalence in peripartum cardiomyopathy. JACC CardioOncol 1(2):196-205

6. Rassaf T, Totzeck M, Backs J et al (2020) Oncocardiology: consensus paper of the German Cardiac Society, the German Society for Pediatric Cardiology and Congenital Heart Defects and the German Society for Hematology and Medical Oncology. Clin Res Cardiol. https://doi.org/10. 1007/s00392-020-01636-7
7. Gredner T, Behrens G, Stock C et al (2018) Cancers due to infection and selected environmental factors. Dtsch Arztebl Int 115(35-36):586-593

8. Ryberg M, Nielsen D, Skovsgaard T et al (1998) Epirubicin cardiotoxicity: an analysis of 469 patients with metastatic breast cancer. JClin Onco 16(11):3502-3508

9. Lubieniecka JM, Graham J, Heffner D et al (2013) A discovery study of daunorubicin induced cardiotoxicity in a sample of acute myeloid leukemia patients prioritizes $\mathrm{P} 450$ oxidoreductase polymorphisms as a potential risk factor. Front Genet 4:231

10. Chatterjee K, Zhang J, Honbo N, Karliner JS (2010) Doxorubicin cardiomyopathy. Cardiology 115(2):155-162

11. Anderlini P, Benjamin RS, Wong FC et al (1995) Idarubicin cardiotoxicity: a retrospective study in acute myeloid leukemia and myelodysplasia. JClin Oncol 13(11):2827-2834

12. Mohan N, Jiang J, Dokmanovic M, Wu WJ (2018) Trastuzumab-mediated cardiotoxicity: current understanding, challenges, and frontiers. Antib Ther 1(1):13-17

13. Choueiri TK, Mayer EL, Je Y et al (2011) Congestive heart failure risk in patients with breast cancer treated with bevacizumab. J Clin Oncol 29(6):632-638

14. Aghel N, Delgado DH, Lipton JH (2017) Cardiovascular toxicities of $B C R-A B L$ tyrosine kinase inhibitors in chronic myeloid leukemia: preventive strategies and cardiovascular surveillance. Vasc Health Risk Manag 13:293-303

15. Ma W, Liu M, Liang F et al (2020) Cardiotoxicity of sorafenib is mediated through elevation of ROS level and CaMKII activity and dysregulation of calcium homoeostasis. Basic Clin Pharmacol Toxicol 126(2):166-180

16. Lipshultz SE, Karnik R, Sambatakos P et al (2014) Anthracycline-related cardiotoxicity in childhood cancer survivors. Curr Opin Cardiol 29(1):103-112

17. Park SJ, Bejar R (2018) Clonal hematopoiesis in aging. Curr Stem Cell Rep 4(3):209-219

18. Thackeray JT, Pietzsch S, Stapel B et al (2017) Insulin supplementation attenuates cancerinduced cardiomyopathy and slows tumor disease progression. JCIInsight 2(10):e93098

19. Karlstaedt A, Zhang X, Vitrac H et al (2016) Oncometabolite d-2-hydroxyglutarate impairs alphaketoglutarate dehydrogenase and contractile function in rodent heart. Proc Natl Acad Sci USA 113(37):10436-10441

20. Ather S, Chan W, Bozkurt B et al (2012) Impact of noncardiac comorbidities on morbidity and mortality in a predominantly male population with heartfailureand preservedversusreduced ejection fraction. JAm Coll Cardiol 59(11):998-1005

21. Hasin T, Gerber Y, McNallan SM et al (2013) Patients with heart failure have an increased risk of incident cancer. J Am Coll Cardiol 62(10):881-886

22. Banke A, Schou M, VidebaekLetal (2016) Incidence of cancer in patients with chronic heart failure: a long-term follow-up study. Eur J Heart Fail 18(3):260-266

23. Hasin T, Gerber Y, Weston SA et al (2016) Heart failure after myocardial infarction is associated with increased risk of cancer. J Am Coll Cardiol 68(3):265-271

24. Libby P, Sidlow R, Lin AE et al (2019) Clonal hematopoiesis: crossroads of aging, cardiovascular disease, and cancer: JACC review topic of the week. JAm Coll Cardiol 74(4):567-577

25. Busque L, Patel JP, Figueroa ME et al (2012) Recurrent somatic TET2 mutations in normal 
elderly individuals with clonal hematopoiesis. Nat Genet 44(11):1179-1181

26. Fuster JJ, MacLauchlan S, Zuriaga MA et al (2017) Clonal hematopoiesis associated with TET2 deficiency accelerates atherosclerosis development in mice. Science 355(6327):842-847

27. Jaiswal S, Fontanillas P, Flannick J et al (2014) Agerelated clonal hematopoiesis associated with adverse outcomes. N Engl JMed 371(26):2488-2498

28. Wells QS, Veatch OJ, Fessel JP et al (2017) Genome-wide association and pathway analysis of left ventricular function after anthracycline exposure in adults. Pharmacogenet Genomics 27(7):247-254

29. Garcia-Pavia P, Kim Y, Restrepo-Cordoba MA, Lunde IG, Wakimoto H, Smith AM et al (2019) Genetic variants associated with cancer therapy-induced cardiomyopathy. Circulation 140(1):31-41

30. Watters JW, Kraja A, Meucci MA et al (2004) Genome-wide discovery of loci influencing chemotherapy cytotoxicity. Proc Natl Acad SciUSA 101(32):11809-11814

31. Ware JS, Li J, Mazaika E et al (2016) Shared genetic predisposition in peripartum and dilated cardiomyopathies. N Engl J Med 374(3):233-241

32. Broustas CG, Lieberman HB (2014) DNA damage response genes and the development of cancer metastasis. Radiat Res 181(2):111-130

33. Sajjad M, Fradley M, Sun W et al (2017) An exploratory study to determine whether BRCA1 and BRCA2 mutation carriers have higher risk of cardiac toxicity. Genes (Basel) 8(2):59

34. Yang J, Zhang Y, Tong J et al (2018) Dysfunction of DNA damage-inducible transcript 4 in the decidua is relevant to the pathogenesis of preeclampsia. Biol Reprod 98(6):821-833

35. Knudson AG Jr (1971) Mutation and cancer: statistical study of retinoblastoma. Proc Natl Acad SciUSA 68(4):820-823

36. Dobrila-Dintinjana R, Vanis N, Dintinjana M, Radić M (2012) Etiology and oncogenesis of pancreatic carcinoma. Coll Antropol 36(3):1063-1067

37. Nassereddine S, Lap CJ, Haroun F, Tabbara I (2017) The role of mutant IDH1 and IDH2 inhibitors in the treatment of acute myeloid leukemia. Ann Hematol 96(12):1983-1991

38. Lipshultz SE, Franco VI, Miller TL et al (2015) Cardiovascular disease in adult survivors of childhood cancer. Annu Rev Med 66:161-176

39. Madonna R, Cadeddu C, Deidda M et al (2017) Modelling chemotherapy-induced cardiotoxicity by human pluripotentstem cells. Curr Drug Targets 18(6):719-723

40. Chang VY, Wang JJ (2018) Pharmacogenetics of chemotherapy-induced cardiotoxicity. Curr Oncol Rep 20(7):52

Fachnachrichten

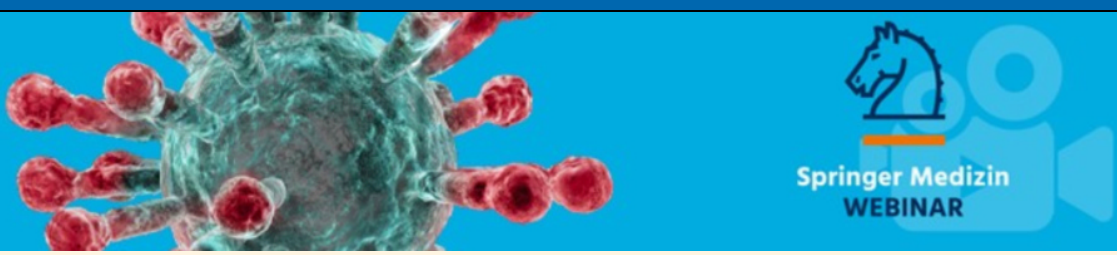

\section{Corona-Webinare bei Springer Medizin}

\section{Webinare und Videointerviews über das Ärzteportal SpringerMedizin.de}

Springer Medizin hat seit April die Initiative Corona-Webinar über sein Ärzteportal (www.springermedizin.de) gestartet. Ärzte, die auf diesem Portal registriert sind, gelangen über Videoseminare an kostenloses Wissen rund um das Corona-Virus. In jedem Webinar oder Videointerview kommt ein Experte zu einem bestimmten Thema zu Wort und gibt fachlich gesichertes Wissen an Kollegen weiter, die sich mit Symptomatik, Diagnostik und Therapie in Klinik und Praxis beschäftigen. Wöchentlich kommen neue Themen hinzu!

Auf der zentralen Corona-Update-Seite auf SpringerMedizin.de sind unter anderem bereits folgende Webinare verfügbar:

- COVID-19: Was wir heute wissen und wie es weitergehen könnte

- Wie COVID-19 und Diabetes zusammenhängen - und was das für die Praxis bedeutet

- COVID-19 überstanden - der mühsame Weg zurück ins Leben

- Zurück zur Routine? Wie meistern wir zukünftige Pandemien?

- Kardiologische Implikationen und Komplikationen von COVID-19

- COVID-19: Pressekonferenz der DGIM Nephrologie, Gastroenterologie, HerzKreislauf-Medizin

- COVID-19 aus kardiologischer Perspektive - ein Update aus China
Alle Webinare sind über www.springermedizin.de/webinare zugänglich, die Seite wird ständig aktualisiert und erweitert.

„In unserer Ärztekommunikation werden wir das Webinar-Format zukünftig stärker nutzen, denn es ist eine sehr wertvolle Ergänzung zu den bestehenden Print- und OnlineAngeboten“, erläutert Cécile Mack, Director Digital Product \& Marketing von Springer Medizin. „Die Inhalte eines Webinars oder VideoInterviews können durch die direkte Ansprache schneller aufgenommen werden. Unsere Redakteure der verschiedenen Magazine und Zeitschriften laden zum Ausbau dieser Initiative ausgewählte Autoren und Herausgeber ein, ihr Fachwissen zu Corona zu teilen. Neben den aktuellen Aspekten werden wir auch in den nächsten Monaten das Thema eng begleiten und über die Erkenntnisse aus klinischen Studien sowie der Entwicklung von Therapieoptionen und Impfstoffen berichten. Solange die SARS-CoV-2/Covid-19-Pandemie eine Bedrohung unserer Gesellschaft darstellt, wird Springer Medizin als ein führender Marktvertreter diese Inhalte kostenfrei vor der Bezahlschranke platzieren, um allen Ärzten eine sichere und fundierte Wissensbasis zu geben. Denkbar ist außerdem, dieses Format auch auf andere medizinische Themen oder zusätzliche Fachgebiete auszudehnen", so die Digitaldirektorin. 